\title{
Chemokine Expression by Glial Cells Directs Leukocytes to Sites of Axonal Injury in the CNS
}

\author{
Alicia A. Babcock, ${ }^{1}$ William A. Kuziel, ${ }^{2}$ Serge Rivest, ${ }^{3}$ and Trevor Owens ${ }^{1}$ \\ ${ }^{1}$ Neuroimmunology Unit, Montreal Neurological Institute, Montreal, Quebec Canada H3A 2B4, ${ }^{2}$ Institute of Cellular and Molecular Biology, University of \\ Texas, Austin, Texas 78712, and ${ }^{3}$ Laboratory of Molecular Endocrinology, Centre Hospitalier de l'Université Laval Research Center and Department of \\ Anatomy and Physiology, Laval University, Quebec, Canada G1V 4G2
}

Innate responses in the CNS are critical to first line defense against infection and injury. Leukocytes migrate to inflammatory sites in response to chemokines. We studied leukocyte migration and glial chemokine expression within the denervated hippocampus in response to axonal injury caused by entorhinodentate lesions. A population of Mac1/CD11b + CD $45^{\text {high }}$ macrophages (distinct from CD $45^{\text {low }}$ microglia) was specifically detected within the lesion-reactive hippocampus by $12 \mathrm{hr}$ after injury. Significant infiltration by CD3 + T cells did not occur in the denervated hippocampus until $24 \mathrm{hr}$ after axotomy. A broad spectrum of chemokines [RANTES/CCL5, monocyte chemoattractant protein (MCP)-1/CCL2, interferon $\gamma$ inducible protein (IP)-10/CXCL10, macrophage inflammatory protein (MIP)-1 $\alpha /$ CCL3, MIP-1 $\beta /$ CCL4, and MIP-2/CXCL2] was induced at this time. RANTES/CCL5 was not significantly elevated until 24 hr after axotomy, whereas MCP-1/CCL2 was significantly induced before leukocyte infiltration occurred. Neither T cells nor macrophages infiltrated the denervated hippocampus of CCR2-deficient mice, arguing for a critical role for the CCR2 ligand MCP-1/CCL2 in leukocyte migration. Both T cells and macrophages infiltrated CCR5-deficient hippocampi, showing that CCR5 ligands (including RANTES/CCL5) are not critical to this response. In situ hybridization combined with immunohistochemistry for ionized binding calcium adapter molecule (iba) 1 or glial fibrillary acidic protein (GFAP) identified iba1 + microglia and GFAP + astrocytes as major sources of MCP-1/CCL2 within the lesion-reactive hippocampus. We conclude that leukocyte responses to CNS axonal injury are directed via innate glial production of chemokines.

Key words: chemokines; CCR2; CCR5; hippocampus; axotomy; microglia; astrocytes; macrophages; T cells; flow cytometry; in situ hybridization; RT-PCR; RNase protection

\section{Introduction}

The CNS has traditionally been regarded as an immunologically privileged organ because of a relatively impermeable bloodbrain barrier and an immunosuppressive microenvironment, which limit immune cell entry and function; however, glial cells may direct innate responses to CNS injury (Carson and Sutcliffe, 1999). Chemokines have emerged as important mediators of glial response.

Chemokines are classified on the basis of the position of conserved cysteine residues into $\mathrm{C}, \mathrm{CC}, \mathrm{CXC}$, and $\mathrm{CX}_{3} \mathrm{C}$ subfamilies. The CC and CXC chemokines are implicated as mediators of both CNS development and inflammation (Meng et al., 1999; Bajetto et al., 2002; Babcock and Owens, 2003). The chemokines monocyte chemoattractant protein (MCP)-1/CCL2, RANTES/ CCL5, macrophage inflammatory protein (MIP)-1 $\alpha /$ CCL3,

Received March 26, 2003; revised July 7, 2003; accepted July 10, 2003.

This research was supported by a grant from the MS Society of Canada to T.0., a grant from the Canadian Institutes of Health Research to S.R., and a Natural Sciences and Engineering Research Council of Canada studentship to A.B. We gratefully acknowledge discussions with and valuable advice from Prof. Bente Finsen (University of Southern Denmark, Odense, Denmark). We thank Maria Caruso for breeding animals and Lyne Bourbonnière for help with RPAs.

Correspondence should be addressed to Trevor Owens, Neuroimmunology Unit, Montreal Neurological Institute, 3801 University Street, Montreal, Quebec Canada H3A 2B4. E-mail: trevor.owens@mcgill.ca.

Copyright $\odot 2003$ Society for Neuroscience $\quad$ 0270-6474/03/237922-09\$15.00/0
MIP-1 $\beta /$ CCL4, and interferon $\gamma$ inducible protein (IP)-10/ CXCL10 are produced by glia and infiltrating leukocytes during multiple sclerosis (MS) and experimental autoimmune encephalomyelitis (EAE) (Glabinski et al., 1995, 1997; Godiska et al., 1995; Berman et al., 1996; McManus et al., 1998; Simpson et al., 1998, 2000; Sorensen et al., 1999, 2002; Van Der Voorn et al., 1999; Babcock and Owens, 2003). Glial chemokine expression in the lesion-reactive facial nucleus may be affected by infiltrating $\mathrm{T}$ cells (Harrison et al., 1998; Raivich et al., 1998; Flugel et al., 2001b). MCP-1/CCL2 and its receptor, CCR2, have been implicated as key mediators of leukocyte entry to CNS, whereas RANTES/CCL5-CCR5 interactions do not appear to be necessary for this response (Fuentes et al., 1995; Kennedy et al., 1998; Fife et al., 2000; Izikson et al., 2000; Siebert et al., 2000; Tran et al., 2000; Huang et al., 2001, 2002; Ousman and David, 2001).

Entorhinodentate axotomy transects fiber tracts that project to the hippocampus, leading to anterograde axonal (Wallerian) and terminal degeneration within this tissue (Fagan and Gage, 1994; Jensen et al., 2000). Glial reactivity has been described at the site of axonal transection and with minimal (Bechmann et al., 2001) or no (Fagan and Gage, 1994; Jensen et al., 1997; Jensen et al., 2000) immune involvement in the denervated hippocampus. Microglial reactivity precedes astroglial activation (Fagan and Gage, 1994; Jensen et al., 1994). Transgenic CNS expression of 
interferon (IFN) $\gamma$ enhanced microglial reactivity without altering kinetics, suggesting that $\mathrm{T}$ cells would modify, but not induce, glial responses (Jensen et al., 2000). Activated microglia express Mac1/CD11b and CD45 (Jensen et al., 1997, 2000; Bechmann et al., 2001). Flow cytometry can discriminate parenchymal microglia $\left(C D 45^{\text {low }}\right)$ from infiltrating macrophages $\left(C D 45^{\text {high }}\right)$ in the inflamed CNS (Sedgwick et al., 1991; Renno et al., 1995; Carson et al., 1998).

We show that entorhinodentate axotomy induces chemokine expression and leukocyte infiltration in the denervated hippocampus. Relative kinetics and analysis of chemokine receptordeficient mice suggest that the CCR2 ligand MCP-1/CCL2 is critical for leukocyte infiltration, whereas CCR5 ligands such as RANTES/CCL5 are not. Our data suggest that glial chemokines direct leukocyte infiltration after CNS injury.

\section{Materials and Methods}

Mice. Female C57BL/6 mice were purchased from Charles River (St. Constant, Quebec, Canada) and kept under pathogen-free conditions. Mice deficient in CCR2 (F2 C57BL/6 × 129/Ola) or CCR5 (eighth generation backcross to C57BL/6) were generated as described previously (Kuziel et al., 1997, 2003) and were bred under pathogen-free conditions. The gross anatomy and organization of the brain is normal in these knock-outs (Tran et al., 2000). Axotomized and control mice weighed between 20 and $30 \mathrm{gm}$. Experiments were conducted according to Canadian Council on Animal Care guidelines, as administered by the McGill University Animal Care Committee.

Surgical procedures. Mice were subjected to wire-knife lesioning of entorhinodentate projections. Under anesthesia, mice were placed in a Kopf stereotactic apparatus (Kopf, Tujunga, CA), and a burr hole was drilled in the skull $1.0 \mathrm{~mm}$ posterior and $2.5 \mathrm{~mm}$ lateral from lambda. A closed wire-knife (Kopf) was inserted at an angle of $14^{\circ}$ anterior and $10^{\circ}$ lateral. At $4.0 \mathrm{~mm}$ ventral to dura, the wire-knife was unfolded, and entorhinodentate axons were transected by retracting the knife $3.5 \mathrm{~mm}$ dorsally. Sham-operated mice were treated the same way as the lesioned animals except that the wire-knife was not inserted into the brain. In all experiments, the lesion-reactive hippocampus was examined independently of the injured entorhinal cortex. The unlesioned hippocampus served as a control, as did hippocampi from unmanipulated or shamoperated mice. Entorhinodentate lesions reproducibly provoked glial reactivity at the site of axonal transection (stab wound) and in the lesionreactive hippocampus (including the fimbria). Glial activation within the fimbria is consistent with lesion-induced retrograde degeneration, as has been described previously (Bechmann et al., 2001).

Flow cytometry. Contralateral and lesion-reactive hippocampi were microdissected from PBS-perfused mice between $3 \mathrm{hr}$ and $14 \mathrm{~d}$ after axotomy. Tissue surrounding the site of axonal transection was discarded. Single-cell suspensions of individual hippocampi were prepared using a $70 \mu \mathrm{m}$ mesh (VWR, Ville Mont-Royal, Quebec, Canada). Cells were centrifuged at $1200 \mathrm{rpm}$ for $10 \mathrm{~min}$ at $4^{\circ} \mathrm{C}$, washed with HBSS (Life Technologies, Burlington, Ontario, Canada), and then incubated with supernatant from the anti-FcR 24G2 hybridoma containing $2 \%$ fetal calf serum (FCS) (Sigma, Oakville, Ontario, Canada) and $50 \mu \mathrm{g} / \mathrm{ml}$ hamster IgG (BIO/CAN Scientific, Mississauga, Ontario, Canada) on ice for 30 min. Cells were washed with FACS buffer (HBSS with $2 \%$ FCS $+0.1 \%$ sodium azide) and then incubated with primary antibody [anti-CD45, anti-CD3 $\epsilon$, anti-T cell receptor $\beta$, anti-Mac1/CD11b, or anti-keyhole limpet hemocyanin (isotype control); $\mathrm{BD}$, Mississauga, Ontario, Canada] on ice for $30 \mathrm{~min}$. Cells stained with biotinylated antibody were washed and then incubated with streptavidin-phycoerythrin (BD). Cells were then washed and staining was analyzed using Cell Quest Pro on a FACScan (BD).

RNase protection assay. At $24 \mathrm{hr}$ after axotomy, the contralateral and lesion-reactive hippocampi were microdissected from PBS-perfused mice, and the tissue surrounding the site of axonal transection was collected separately. RNA was purified using Trizol. RNase protection assay (RPA) using multiprobe DNA templates for chemokines (lymphotactin/
XCL1, RANTES/CCL5, eotaxin/CCL11, MIP- $1 \alpha / C C L 3$, MIP-1 $\beta / C C L 4$, MIP-2/CXCL2, IP-10/CXCL10, MCP-1/CCL2 and TCA-3/CCL1) and for housekeeping genes (L32 and GAPDH) was performed according to the manufacturer's protocol (BD). Briefly, T7 polymerase was used to create antisense riboprobes from DNA templates, which were then labeled with $\left[\alpha_{-}{ }^{32} \mathrm{P}\right] \mathrm{UTP}$ (Perkin-Elmer, Markham, Ontario, Canada). Labeled probes were hybridized with 7-8 $\mu \mathrm{g}$ of total RNA, digested with RNase, and then treated with proteinase K. RNase-protected RNA duplexes were extracted with phenol/chloroform/isoamyl alcohol (VWR) and resolved on $5 \%$ denaturing polyacrylamide gels using undigested labeled probes as size markers. After an exposure time of $4 \mathrm{~d}$, dried gels were visualized and quantified by PhosphorImager (Molecular Dynamics, Sunnyvale, CA) and then subsequently analyzed using ImageQuant v. 1.1 for Apple Macintosh.

RT-PCR. At 3, 12, 24, or $48 \mathrm{hr}$ after axotomy, mice were perfused transcardially with PBS. The contralateral and lesion-reactive hippocampi were microdissected; tissue surrounding the site of axonal transection was collected separately. RNA was purified using Trizol (Life Technologies) and then reverse transcribed as described previously from microdissected hippocampus (Jensen et al., 2000). PCR conditions were optimized for linear amplification to allow direct comparison between samples (Renno et al., 1994). Equal amounts of cDNA were amplified using $1 \times$ PCR buffer (Sigma), $2 \mathrm{~mm} \mathrm{MgCl}_{2}$ (Sigma), $80 \mathrm{~mm}$ each of dNTPs (Pharmacia, Baie d'Urfé, Canada), 2 U of Taq polymerase (Sig$\mathrm{ma}$ ), and $50 \mathrm{pmol}$ of each primer (Life Technologies). The PCR reaction was performed using an Eppendorf thermocycler (VWR) for 28 cycles with denaturation, annealing, extension conditions optimized for each primer set: MCP-1/CCL2 $\left(94^{\circ} \mathrm{C}\right.$ for $30 \mathrm{sec}, 57^{\circ} \mathrm{C}$ for $30 \mathrm{sec}$, and $72^{\circ} \mathrm{C}$ for $45 \mathrm{sec})$, and RANTES/CCL5 and $\beta$-actin $\left(94^{\circ} \mathrm{C}\right.$ for $30 \mathrm{sec}, 60^{\circ} \mathrm{C}$ for $30 \mathrm{sec}$, and $72^{\circ} \mathrm{C}$ for $\left.1 \mathrm{~min}\right)$. To prevent saturation of $\beta$-actin mRNA, cDNA samples were diluted 1:15 with water. The primer sequences for RANTES/CCL5 were as follows: sense, CCC TCA CCA TCA TCC TCA CT; antisense, GGG AAG CGT ATA CAG GGT CA. The other primer sequences were described previously as follows: $\beta$-actin (Renno et al., 1998) and MCP-1/CCL2 (Maatta et al., 1998). PCR products were electrophoresed in a $2 \%$ agarose gel, visualized by ethidium bromide, and analyzed by Gene Genius (Fisher, Montreal, Canada).

In situ hybridization. Mice were perfused transcardially with PBS, followed by 0.1 м Borax-buffered $4 \%$ paraformaldehyde (PFA), $\mathrm{pH} 9.5$ at $4^{\circ} \mathrm{C}$, at $24 \mathrm{hr}$ after axotomy. Brains were removed, postfixed for $4-6 \mathrm{~d}$, and then fixed overnight in $10 \%$ sucrose in $4 \%$ PFA-Borax buffer. The brains were frozen and cut into $20 \mu \mathrm{m}$ coronal sections on a microtome (Reichert-Jung, Cambridge Instruments, Deerfield, IL), from the olfactory bulb to the caudal medulla. Sections were collected in a cryoprotectant solution $(0.05 \mathrm{~m}$ sodium phosphate buffer, $\mathrm{pH} 7.3$, containing $30 \%$ ethylene glycol and $20 \%$ glycerol) and stored at $-20^{\circ} \mathrm{C}$. The sections were exposed overnight at $4^{\circ} \mathrm{C}$ to $\mathrm{x}$-ray films (Kodak, Rochester, NY), defatted in xylene, dipped into NTB2 nuclear emulsion (Kodak; diluted 1:1 with distilled water), and exposed for $14 \mathrm{~d}$ before being developed and counterstained with thionin $(0.25 \%)$. Generation of the MCP-1/CCL2 riboprobes was as described (Thibeault et al., 2001).

Combined immunohistochemistry and in situ hybridization. Immunohistochemistry was combined with in situ hybridization (ISH) to identify the cellular source of MCP-1/CCL2 in the lesion-reactive hippocampus. Every sixth brain section was processed by the avidin-biotin method with peroxidase as a substrate, as described previously (Thibeault et al., 2001). Microglia were labeled with an antibody against iba1, previously described to be specific for microglial cells (generously provided by Dr. Y. Imai, National Institute of Neuroscience, Kodaira, Tokyo, Japan) (Ito et al., 1998). Astrocytes were labeled with an antibody against glial fibrillary acidic protein (GFAP) (DAKO, Mississauga, Canada). Briefly, sections were rinsed with K-PBS and incubated with primary antibody. Sections were once more rinsed in K-PBS, incubated with biotinylated secondary antibodies (Vector Laboratories), and then rinsed again with K-PBS before a final incubation with an avidin-biotin-peroxidase complex (Vectastain ABC Elite kit, Vector Laboratories). After several washes in $\mathrm{K}-\mathrm{PBS}$, the brain slices were reacted in $0.05 \%$ diaminobenzidine and $0.003 \%$ hydrogen peroxide. Thereafter, sections were rinsed in K-PBS, mounted, dessicated, fixed in $4 \% \mathrm{PFA}$, and digested by proteinase $\mathrm{K}$. 
Prehybridization, hybridization, and posthybridization steps were performed according to the above description, with shorter dehydration times (alcohol 50, 70, 95, 100\%) to prevent decoloration of immunoreactive cells. The slides were dried and then exposed and developed as described above.

For proportional counts, MCP-1/CCL2+ cells were identified at high magnification and then examined for ibal or GFAP expression by bright-field microscopy. MCP-1/CCL2+ cells located within the lesion-reactive hippocampus were considered separately from those found at the site of axonal transection.

\section{Results}

Macrophages infiltrate the

lesion-reactive hippocampus

Previous studies using immunohistochemistry to document microglial activation in the denervated hippocampus did not describe infiltrating macrophages ( Fagan and Gage, 1994; Jensen et al., 1997). Flow cytometry can distinguish between macrophages and microglia in cellular isolates from inflamed tissues. Although both microglia and macrophages express Mac1/ CD11b, microglia express lower levels of CD45 (Sedgwick et al., 1991; Renno et al., 1995; Carson et al., 1998). We used flow cytometry to characterize macrophage and microglial responses in individual hippocampi after axonal injury. Very few $\mathrm{Mac1/CD} 11 \mathrm{~b}+\mathrm{CD} 45^{\text {high }}$ cells were identified in unmanipulated hippocampi $(0.12 \pm 0.02 \%)$ (Fig. $1 A, D)$. These were close to the limit of detection and were likely perivascular macrophages. A similar proportion of $\mathrm{Mac1} / \mathrm{CD} 1 \mathrm{~b}+\mathrm{CD} 45^{\text {high }}$ macrophages was detected in contralateral hippocampi between $3 \mathrm{hr}$ and $14 \mathrm{~d}$ after axotomy (Fig. 1A,D). The percentage of macrophages in the lesion-reactive hippocampus was not significantly different from controls at $3 \mathrm{hr}$ after axotomy $(0.12 \pm 0.03 \%)$ (Fig. $1 D)$. By contrast, by $12 \mathrm{hr}$ after axotomy, the percentage of macrophages in the lesion-reactive hippocampus doubled $(0.25 \pm 0.07 \%$; Fig. $1 D)$. The proportion of infiltrating macrophages further increased by $24 \mathrm{hr}$ after axotomy $(0.66 \pm 0.14 \%)$, peaked at $2 \mathrm{~d}$

$(1.22 \pm 0.46 \%)$, and then declined between $5(0.40 \pm 0.15 \%)$ and $14(0.20 \pm 0.03 \%) \mathrm{d}$ after axotomy (Fig. $1 A, D)$. Macrophage cell proportions within the denervated hippocampus at $24 \mathrm{hr}$ after axotomy represented $\sim 250-300$ macrophages (versus $\sim 50$ in unmanipulated hippocampi). These data suggest that macrophages infiltrate the lesion-reactive hippocampus within $12 \mathrm{hr}$ of axonal injury.

\section{T cells infiltrate the lesion-reactive hippocampus}

Previous studies described either no T cell infiltration or expression of the Th1 cytokine, IFN $\gamma$, after entorhinodentate lesions (Fagan and Gage, 1994; Jensen et al., 1997, 2000), or minimal
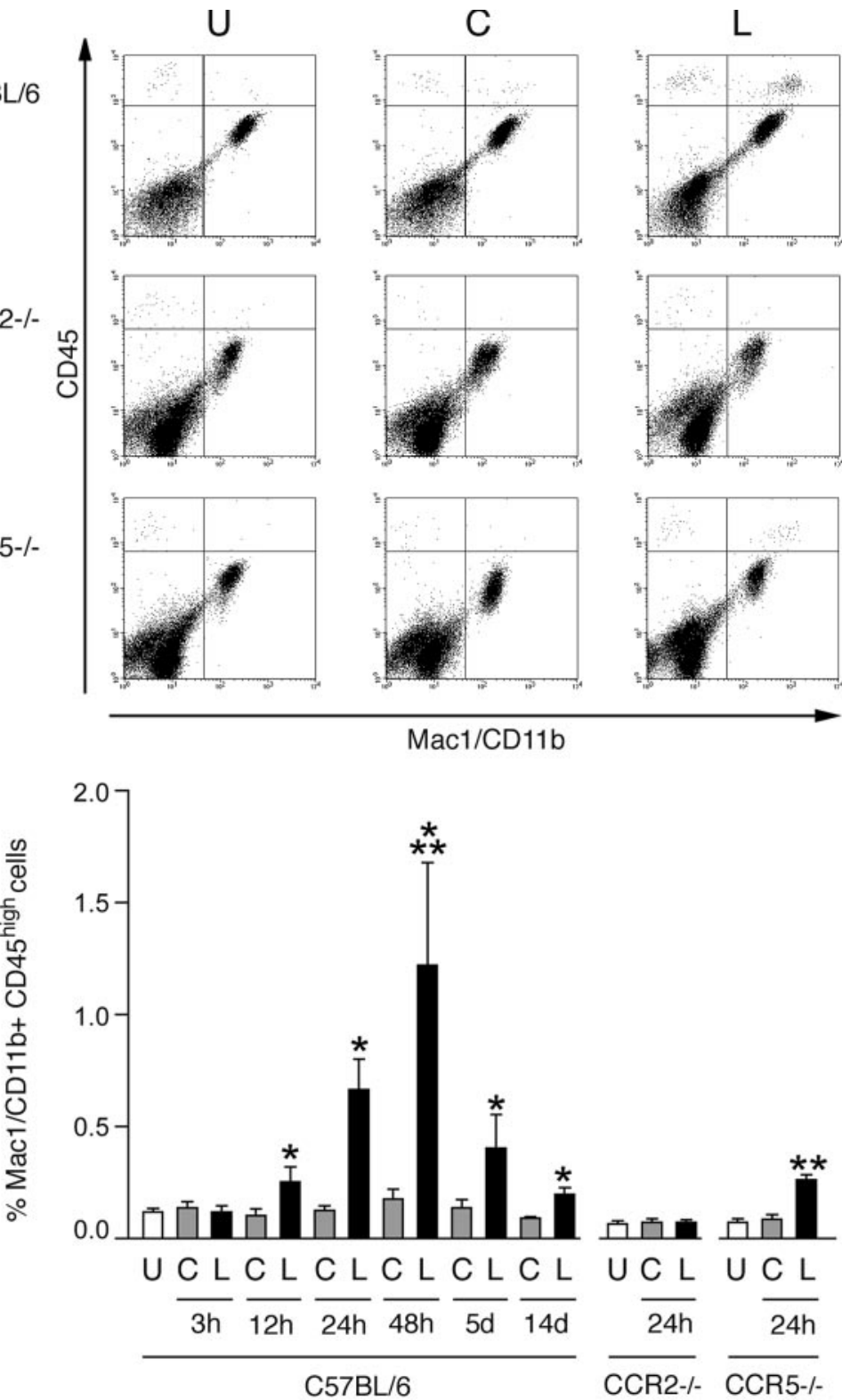

Figure 1. Macrophages infiltrate the lesion-reactive hippocampus. Flow cytometry profiles show live cells on the basis of forward and side scatter gating. Shown are representative profiles from individual unmanipulated (U, left column), contralateral ( $C$, middle column), or lesion-reactive ( $L$, right column) hippocampi from C57BL/6 ( $A)$, CCR2-deficient (B), or CCR5-deficient ( $C$ ) mice at $24 \mathrm{hr}$ after axotomy. Macrophages were identified on the basis of expression of Mac1/CD11b and high levels of CD45 (top (mean $\pm \mathrm{SE}$ ). Quadrants were set on the basis of fluorescence levels using isotype-matched control antibodies. Data are representative of $3-11$ animals per group. ${ }^{*} p<0.05-0.001$ versus $\mathrm{U}$ and $\mathrm{C} ;{ }^{* *} p<0.05-0.001$ versus $\mathrm{U}, \mathrm{C}$, and L of $\mathrm{C} 57 \mathrm{BL} / 6 \mathrm{at} 24 \mathrm{hr}$; ${ }^{* *} p<0.05-0.001$ versus $\mathrm{U}, \mathrm{C}$, and $\mathrm{L}$.

infiltration at later times (Bechmann et al., 2001). We used flow cytometry to detect CD3, a marker for all T cells. Only cells that expressed high levels of CD45 showed increased fluorescence with anti-CD3 compared with isotype-matched control antibody. This identifies them as $\mathrm{T}$ cells. A very low frequency of $\mathrm{CD} 3+$ cells was identified in isolates from unmanipulated hippocampi $(0.09 \pm 0.03)$ (Fig. $2 A, D)$. Similarly few CD3 + T cells were found in contralateral or lesion-reactive hippocampi between $3 \mathrm{hr}$ and $14 \mathrm{~d}$ after axotomy (Fig. $2 A, D$ ). A significant increase in the frequency of $\mathrm{T}$ cells in the lesion-reactive hippocampus was first detected $24 \mathrm{hr}$ after axotomy $(0.27 \pm 0.05 \%)$ (Fig. $2 A, D$ ). A similar proportion of T cells was identified within 

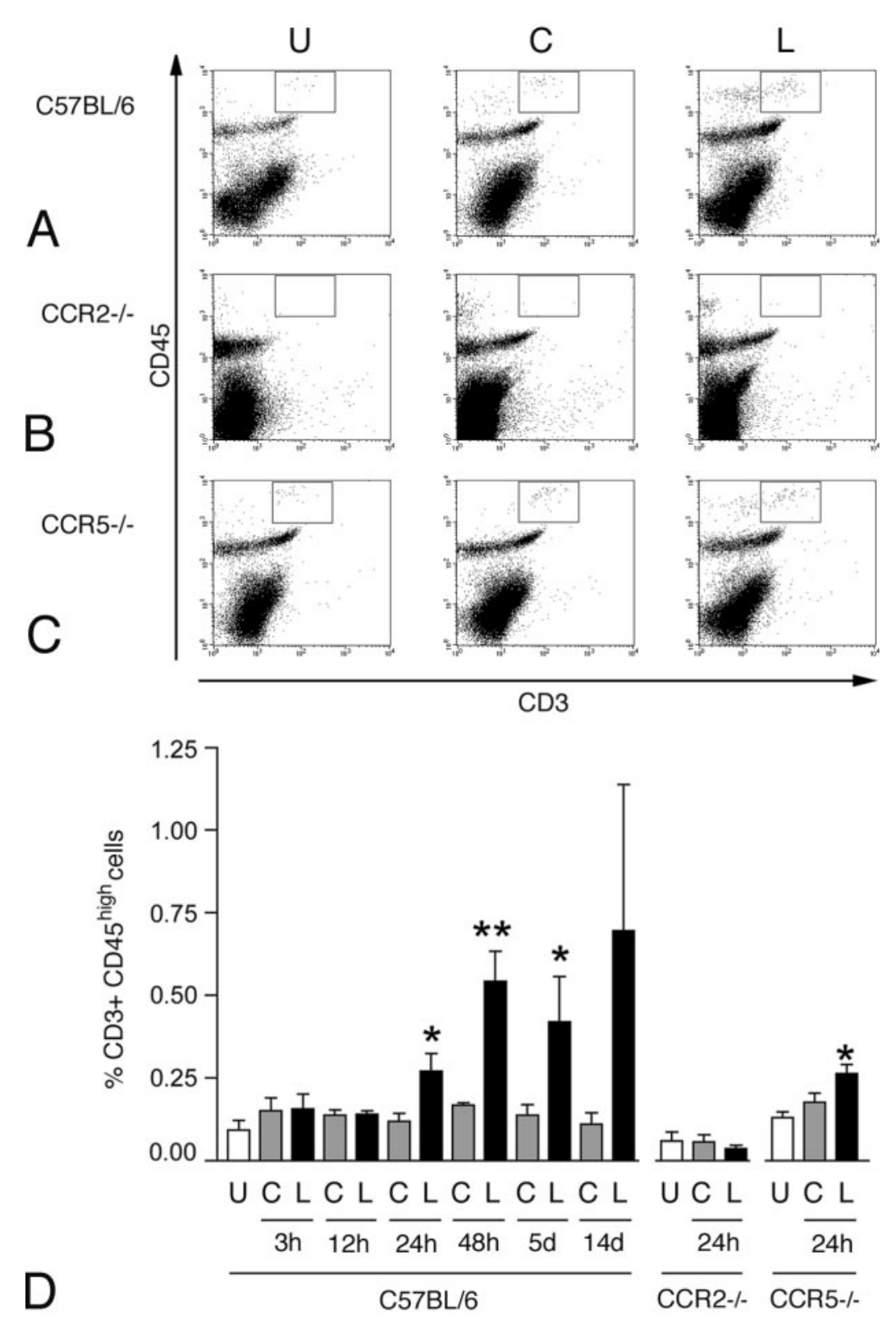

Figure 2. T cells infiltrate the lesion-reactive hippocampus. Flow cytometry profiles show live cells on the basis of forward and side scatter gating. Shown are representative profiles from individual unmanipulated (U, left column), contralateral (C, middle column), or lesion-reactive (L, right column) hippocampi from C57BL/6 (A), CCR2-deficient ( $B$ ), or CCR5-deficient (C) mice at 24 $\mathrm{hr}$ after axotomy. T cells were identified on the basis of expression of CD3 and CD45 (box). D shows T cell proportions within groups of hippocampi between $3 \mathrm{hr}$ and $14 \mathrm{~d}$ after axotomy (mean $\pm \mathrm{SE}$ ). Boxes were drawn on the basis of fluorescence levels using isotype-matched control antibodies. Data are representative of three to seven animals per group. ${ }^{*} p<0.05$ versus $\mathrm{U}$ and $\mathrm{C} ;{ }^{* *} p<$ $0.05-0.001$ versus $\mathrm{U}, \mathrm{C}$, and $\mathrm{L}$ of $\mathrm{C} 57 \mathrm{BL} / 6$ at 3,12 , and $24 \mathrm{hr}$.

the lesion-reactive hippocampus at $24 \mathrm{hr}$ after axotomy using antibodies against TCR $\beta(0.24 \pm 0.01 \%)$. Infiltration by T cells at this time was more variable than infiltration by macrophages, to the extent of being undetectable in two of seven lesioned mice. The proportion of $\mathrm{T}$ cells at $24 \mathrm{hr}$ after axotomy represents $\sim 100-150 \mathrm{~T}$ cells in the denervated hippocampus compared with $\sim 50$ in unmanipulated hippocampi. A greater proportion of $\mathrm{T}$ cells was found by $2 \mathrm{~d}(0.54 \pm 0.09 \%)$ and remained elevated through $5(0.42 \pm 0.14 \%)$ and $14(0.70 \pm 0.44 \%)$ d after axotomy (Fig. 2D). These data suggest that $\mathrm{T}$ cell infiltration of the lesionreactive hippocampus is variable and minor compared with macrophages at early times, whereas at later times $\mathrm{T}$ cells outnumber macrophages.

\section{Axonal injury induces} chemokine expression

Constitutive expression of chemokines was not detected by RPA in unmanipulated hippocampi (Fig. 3A). Message for RANTES/CCL5, MCP-1/CCL2, IP-10/ CXCL10, MIP- $1 \alpha /$ CCL3, MIP-1 $\beta /$ CCL4, and MIP-2/CXCL2 was specifically induced in the lesion-reactive hippocampus and at the site of axonal transection by 24 hr after axotomy (Fig. 3A). Lymphotactin/ XCL1, eotaxin/CCL11, and TCA-3/CCL1 were not detected. Chemokine signals were normalized to L32 for comparison between treatments and sources of RNA (Fig. 3B). Levels of MCP-1/CCL2, RANTES/CCL5, IP-10/CXCL10, MIP-1 $\alpha /$ CCL3, and MIP$1 \beta /$ CCL4 expression were significantly elevated in the lesion-reactive hippocampus and at the site of axonal transection. MIP-2/ CXCL2 was only significantly induced at the site of axonal transection. Thus, axonal injury induces expression of a wide spectrum of chemokines.

\section{Kinetics of RANTES/CCL5 and MCP-1/CCL2 expression}

We examined levels of RANTES/CCL5 and MCP-1/CCL2 expression by RT-PCR at $3,12,24$, and $48 \mathrm{hr}$ after axotomy. Normalization to $\beta$-actin allowed the level of expression to be compared with control hippocampi. MCP-1/CCL2 was significantly elevated in the denervated hippocampus and at the site of axonal transection as early as $3 \mathrm{hr}$ after axotomy, compared with unmanipulated and sham controls (Fig. 4A,B). RANTES/CCL5 was only significantly elevated in the lesionreactive hippocampus by 24 and $48 \mathrm{hr}$ after axotomy and only significantly induced at the site of axonal transection between 12 and $48 \mathrm{hr}$ after axotomy (Fig. $4 A, C)$. Levels of expression before $48 \mathrm{hr}$ after axotomy were generally higher at the site of axonal transection than in the lesion-reactive hippocampus (Fig. 4B,C). A slight sham effect was seen for RANTES at $3 \mathrm{hr}$ and for MCP-1/CCL2 at $12 \mathrm{hr}$, but not at other times (Fig. $4 B, C$ ). Despite sharing similar kinetics with RANTES/ CCL5 at later times, MCP-1/CCL2 was therefore uniquely elevated at $3 \mathrm{hr}$ after axotomy. These data suggest that early expression of MCP-1/CCL2 may be responsible for leukocyte recruitment to the denervated hippocampus.

Levels of MCP-1/CCL2 protein in the lesion-reactive hippocampus were less than the limit of detection using immunostaining or Western blot $(\sim 1 \mathrm{ng}$ recombinant MCP-1/CCL2; data not shown). This is broadly consistent with other studies that showed infiltrating leukocytes as major producers of MCP1/CCL2 in EAE, with similar detection thresholds (Nygardas et al., 2000; Rajan et al., 2000). As shown below, we find glial cells to be major sources of MCP-1/CCL2. 
Leukocyte infiltration depends on signaling through CCR2, not CCR5 The chemokine MCP-1/CCL2 signals almost exclusively through the CCR2 receptor (Gu et al., 1999). We tested directly whether signaling through CCR2 directs leukocyte infiltration in response to axonal injury by lesioning CCR2-deficient mice. We also examined injury responses in CCR5-deficient mice. Glial activation did not appear to be impaired in these mice. Upregulation of Mac1/CD11b on CD $45^{\text {low }}$ cells in hippocampus, detected by flow cytometry $24 \mathrm{hr}$ after axotomy, was equivalent to wild-type mice. Immunohistochemical staining for GFAP was also not changed. There was no evidence for a shift in chemokine profile at $24 \mathrm{hr}$ (data not shown).

As in wild-type mice, very few macrophages were identified within unmanipulated or contralateral hippocampi from either knock-out (Fig. 1B-D). Unlike wildtype mice, in which macrophages increased $\sim 5.5$-fold in the lesion-reactive hippocampus, macrophages did not infiltrate the denervated hippocampus of CCR2-deficient mice $(0.07 \pm 0.01 \% ; p>0.05)$ (Fig. $1 B, D$ ). A low but significantly elevated frequency of macrophages was found in the denervated hippocampus of CCR5-deficient mice (3.5fold; $0.26 \pm 0.02 \%$ ) (Fig. 1C,D). These data point to MCP-1, the functional ligand for CCR2, as being critical for macrophage infiltration, unlike CCR5 ligands, such as RANTES/CCL5.

Unlike wild-type mice, in which $\mathrm{T}$ cells increased approximately threefold in the lesion-reactive hippocampus, $\mathrm{T}$ cells did not infiltrate the denervated hippocampus of CCR2-deficient mice $(0.04 \pm 0.01 \%)$ (Fig. $2 B, D$ ). MCP-1/CCL2 is therefore also a critical mediator of $\mathrm{T}$ cell infiltration. By contrast, $\mathrm{T}$ cell infiltration to the denervated hippocampus of CCR5deficient mice was indistinguishable from controls $(0.26 \pm 0.03 \%$ ) (Fig. $2 C, D)$, and so CCR5 ligands are not critical for $\mathrm{T}$ cell entry to sites of axonal injury.

\section{Microglia and astrocytes express MCP-1/CCL2 transcripts}

We examined MCP-1/CCL2 mRNA expression by ISH at $24 \mathrm{hr}$ after axotomy. No MCP-1/CCL2+ cells were found in unmanipulated hippocampus (Fig. 5A). MCP-1/CCL2+ cells were almost undetectable in contralateral hippocampi at $24 \mathrm{hr}$ after axotomy (Fig. 5C). Cells strongly positive for MCP-1/CCL2 transcripts were localized to the site of axonal transection and within the lesion-reactive hippocampus, particularly in the molecular layers and fimbria (Fig. $5 B, D$ ).

We combined ISH with immunohistochemistry for ibal, a microglial marker, and for GFAP, which labels astrocytes, to identify cells producing MCP-1/CCL2 after entorhinodentate lesions. Approximately two-thirds of MCP-1/CCL2+ cells in the denervated hippocampus colocalized with ibal immunoreactiv-

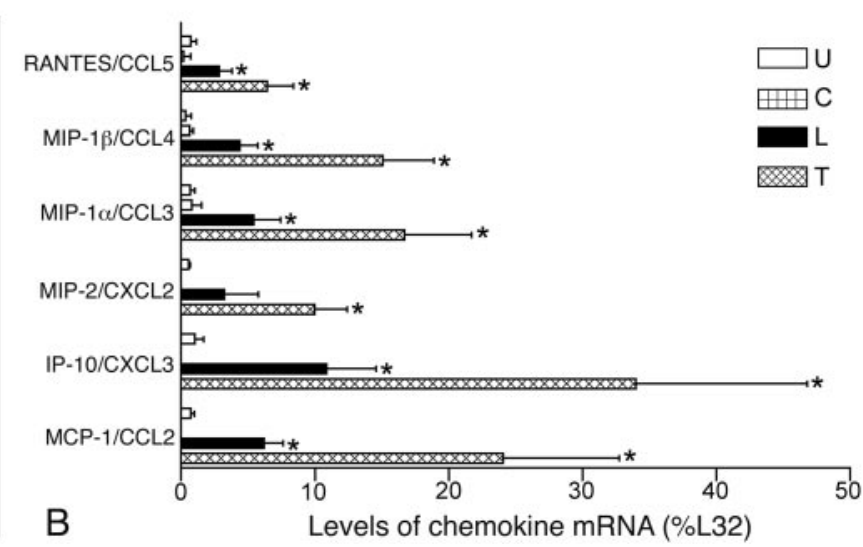

Figure 3. Axonal injury induces chemokine expression. RPA of chemokine expression in perfused hippocampi of C57BL/6 mice at $24 \mathrm{hr}$ after axotomy shows that MCP-1/CCL2, RANTES/CCL5, IP-10/CXCL10, MIP-1 $\alpha / C \mathrm{CL} 3$, MIP-1 $\beta / C \mathrm{CL} 4$, and MIP-2/CXCL2 were specifically induced in the lesion-reactive hippocampus and at the site of axonal transection. Results are representative of four separate experiments. U, Unmanipulated hippocampus; C, contralateral unlesioned hippocampus; L, lesion-reactive hippocampus; $T$, site of axonal transection. ${ }^{*} p<0.05-0.01$ versus $U$ and $C$.
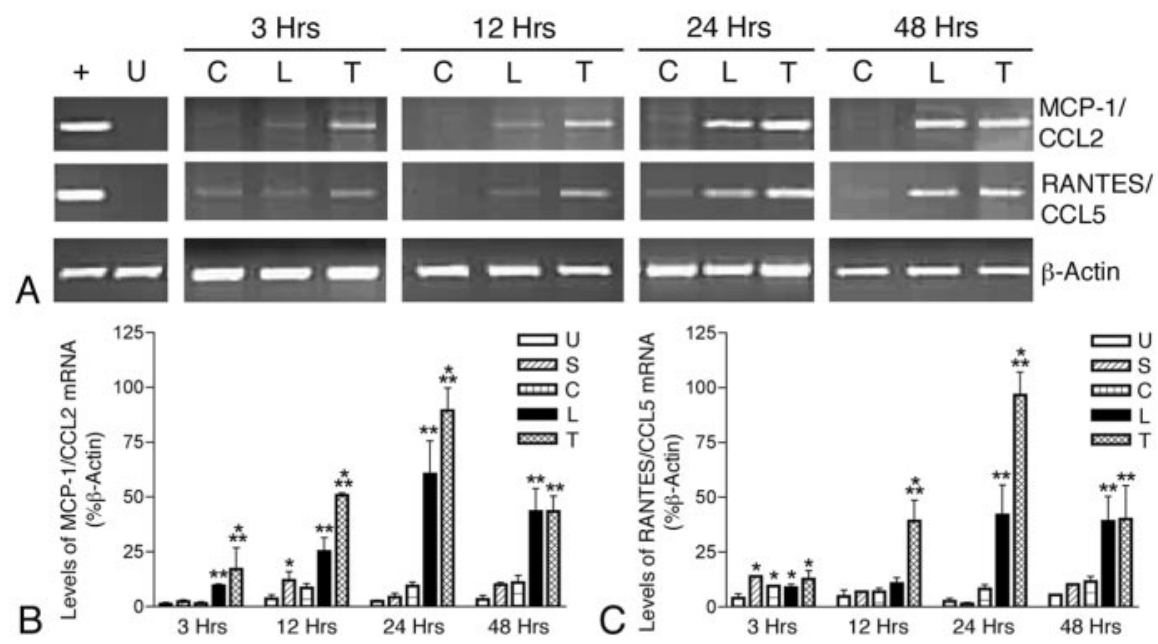

Figure 4. Message for MCP-1/CCL2 and RANTES/CCL5 is induced by axotomy. A, RT-PCR analysis of MCP-1/CCL2, RANTES/CCL5, and $\beta$-actin mRNA from perfused hippocampus of $C 57 \mathrm{BL} / 6$ mice at 3, 12, 24, or $48 \mathrm{hr}$ after axotomy. Levels of MCP-1/CCL2 (B) and RANTES/CCL5 ( $C$ ) amplimers were determined by fluroimager analysis and then normalized to $\beta$-actin. Data are representative of sham-operated hippocampus; $C$, contralateral unlesioned hippocampus; L, lesion-reactive hippocampus; T, site of axonal transection. ${ }^{*} p<0.01-0.001$ versus $U$; ${ }^{* *} p<0.01$ versus $U, S$, $C_{;}^{* * *} p<0.01-0.001$ versus $U, S, C$, and $L$.

ity, revealing microglia as the predominant source of chemokine at $24 \mathrm{hr}$ after axotomy (Fig. 6D,E, Table 1). Estimates of iba1+ MCP-1/CCL2 + cells on the basis of counts in tissue sections outnumbered the Mac1/CD11b + CD $45^{\text {high }}$ cells identified in the denervated hippocampus by flow cytometry by approximately two orders of magnitude, arguing against infiltrating iba $1+$ macrophages as a prominent source of this chemokine. Not all ibal+ microglia expressed MCP-1/CCL2 transcripts. GFAP+ astrocytes within denervated regions also contributed to MCP-1/ CCL2 expression (Fig. 6A-C, Table 1). The proportion of GFAP + MCP-1/CCL2 + cells matched the proportion of iba1MCP-1/CCL2 + cells, suggesting that astrocytes and microglia account for essentially all MCP-1/CCL2 production at this time. We confirmed astroglial activation in the denervated hippocampus by RT-PCR for GFAP (data not shown). Most of the MCP$1 /$ CCL $2+$ cells at the site of axonal transection were astrocytes (Table 1). 

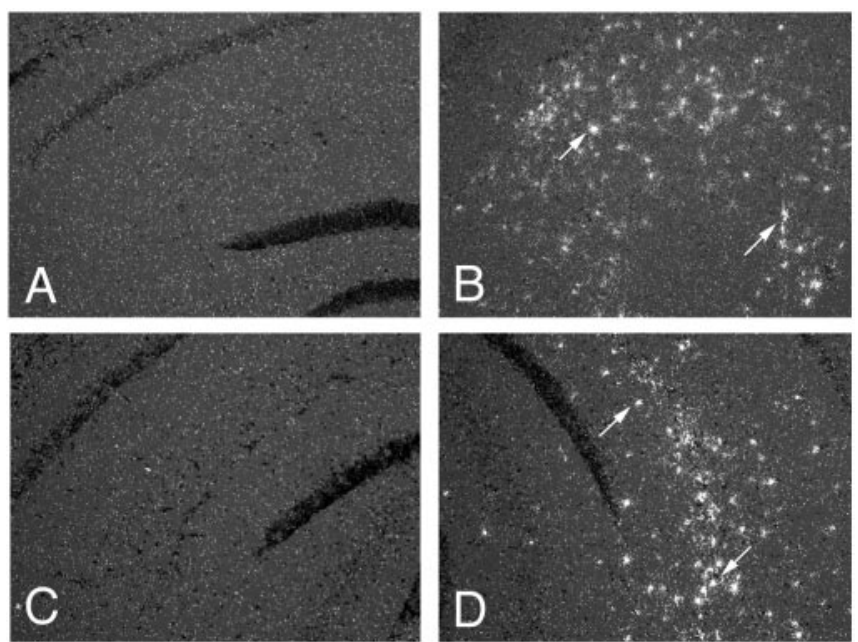

Figure 5. Axotomy induces $M C P-1 / C C L 2$ expression within the denervated hippocampus. $\mathrm{MCP}-1 / \mathrm{CCL} 2+$ cells were not detected by in situ hybridization in coronal sections from unmanipulated hippocampus $(A)$ or contralateral unlesioned hippocampus after axotomy $(C)$. Numerous robustly positive cells were found in the lesion-reactive hippocampus $(D)$, located distally to the site of axonal transection $(B)$. Original magnification, $10 \times$

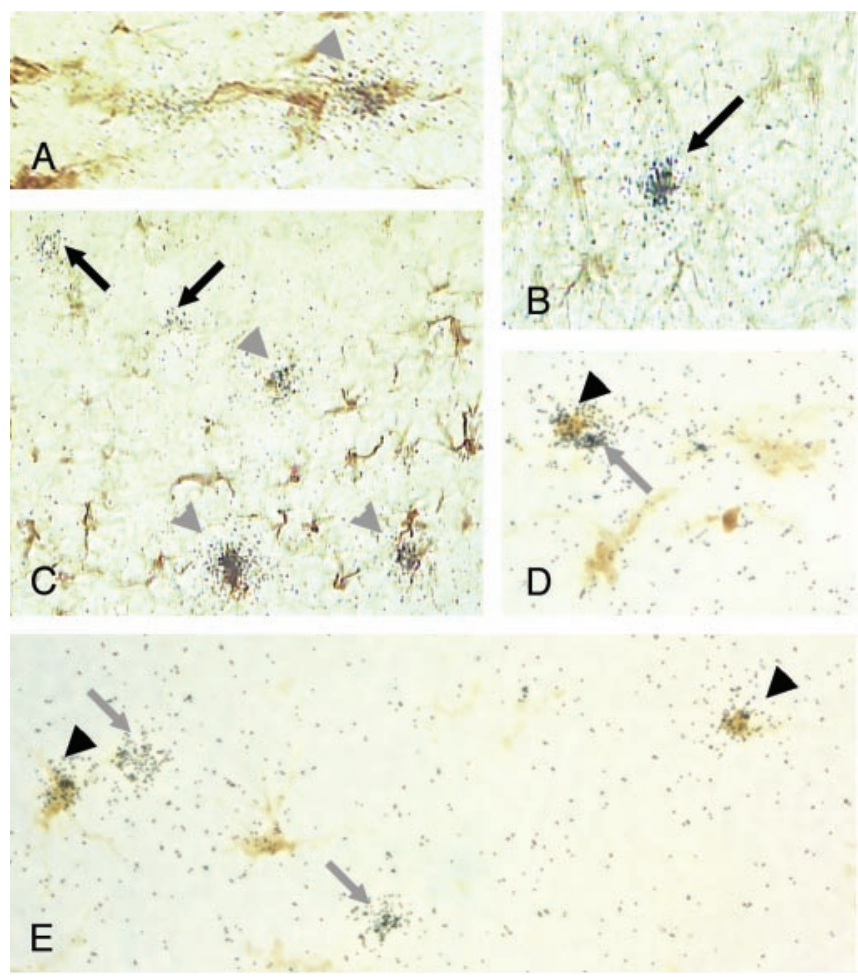

Figure 6. Microglia and astrocytes express MCP-1/CCL2 transcripts. Immunohistochemistry and in situ hybridization were combined to determine the cellular source of chemokine expression. Brown immunoreactivity for GFAP or iba1 identifies astrocytes $(A-C)$ and microglia $(D, E)$,

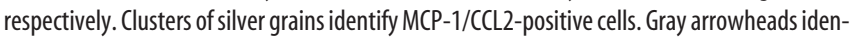
tify GFAP + astrocytes $(A, C)$, and black arrowheads identify iba1 + microglia $(D, E)$ that express $\mathrm{MCP}-1 / \mathrm{CCL} 2$. Black arrows show GFAP- $(B, C)$ and gray arrows show iba1- $(D, E) \mathrm{MCP}-1 / \mathrm{CCL} 2+$ cells. In $D$, a microglial cell and an astrocyte are juxtaposed. Original magnification, $60 \times$; except C $(40 \times)$.

\section{Discussion}

We have identified macrophages and T cells within the lesionreactive hippocampus after entorhinodentate axotomy. Axonal injury provoked the expression of CC and CXC chemokines, including RANTES/CCL5 and MCP-1/CCL2. Kinetic studies and lesions in CCR5-deficient mice suggest that leukocyte recruitment did not depend on RANTES/CCL5-CCR5 interactions. Early expression of MCP-1/CCL2 and abrogation of lesioninduced leukocyte infiltration in mice deficient in its receptor, CCR2, support a critical role for this chemokine. Microglia and astrocytes were prominent sources of MCP-1/CCL2. Our data suggest that innate glial responses direct leukocyte entry to the injured CNS by means of chemokine production.

Macrophage infiltration has not been described previously after entorhinodentate lesions (Fagan and Gage, 1994; Jensen et al., 1997). This may reflect the rapid decline in macrophage numbers several days after lesion or relate to difficulties in discriminating macrophages from microglia by histological analyses. When activated, these cell types become phenotypically equivalent, with the exception of CD45 levels, which have been used to discriminate resting parenchymal microglia $\left(\mathrm{CD} 45^{\text {low }}\right)$ from infiltrating macrophages (CD45 high $)$ in the inflamed CNS (Sedgwick et al., 1991; Renno et al., 1995; Carson et al., 1998). This is the first study to use flow cytometry to make this distinction after axonal injury. Perivascular macrophages, which also express a $\mathrm{Mac} 1 / \mathrm{CD} 11 \mathrm{~b}+\mathrm{CD} 45^{\text {high }}$ phenotype, are seen at very low frequencies in unmanipulated hippocampi. Studies have shown that activated microglia upregulate CD45 (Jensen et al., 1997; Sedgwick et al., 1998; Carson et al., 1999), but this does not obscure the difference between microglia and macrophages (Renno et al., 1995). Nevertheless, it remains possible that Mac1/CD11b+ CD $45^{\text {high }}$ cells include activated microglia. Rigorous analysis requires a bone-marrow chimera approach. Such studies have in fact shown that blood-derived cells can enter the CNS and become morphologically indistinguishable from microglia (Flugel et al., 2001a; Priller et al., 2001; Vallieres and Sawchenko, 2003). We assume that the Mac1/CD11b + CD $45^{\text {high }}$ cells in our study are infiltrating macrophages, responding to glial production of the macrophage chemoattractant MCP-1/CCL2.

Macrophages infiltrate after CNS insult, and MCP-1/CCL2 has been implicated as a key mediator of this response. Our results show that CCR2 was required for both macrophage and $\mathrm{T}$ cell infiltration of the denervated hippocampus. These functional data confirm production of bioactive MCP-1/CCL2 protein. Macrophage infiltration was reduced after injury to sciatic nerve or spinal cord in mice deficient in CCR2 (Siebert et al., 2000; Ma et al., 2002), or after lysophosphatidylcholine-induced demyelination after treatment with neutralizing antibodies against MCP1/CCL2 (Ousman and David, 2001). Transgenic overexpression of MCP-1/CCL2 caused leukocyte accumulation within cerebral vessels (Fuentes et al., 1995; Huang et al., 2002). Knock-out and antibody depletion studies have implicated MCP-1/CCL2 and CCR2 as critical mediators for induction and progression of EAE, by reducing macrophage and $\mathrm{T}$ cell infiltration of the CNS (Kennedy et al., 1998; Fife et al., 2000; Izikson et al., 2000; Huang et al., 2001). MCP-1 production by human brain endothelial cells directly provoked transendothelial migration by CCR2 + Th2 cells in vitro (Biernacki et al., 2001). By contrast, macrophage infiltration was required for $\mathrm{T}$ cell infiltration to initiate $\mathrm{EAE}$ (Martiney et al., 1998; Tran et al., 1998). Whether macrophage infiltration promotes later infiltration by $\mathrm{T}$ cells is an interesting possibility.

Previous studies have described either no (Fagan and Gage, 1994; Jensen et al., 2000) or minimal (Bechmann et al., 2001) infiltration by $\mathrm{T}$ cells after entorhinodentate lesions. Our study suggests that $\mathrm{T}$ cell infiltration begins at $24 \mathrm{hr}$ after axotomy, after macrophages have entered the denervated hippocampus. It is 
important to note that early $\mathrm{T}$ cell responses were less marked and more variable than macrophage responses. There were individual mice in which $\mathrm{T}$ cell infiltration was not detectable at these times, although macrophage infiltrates were. By contrast, more $\mathrm{T}$ cells than macrophages infiltrated at later times. The number of $\mathrm{T}$ cells that infiltrate the denervated hippocampus 1-2 d after lesion correspond to those counted in histological sections in a separate study (R. Ladeby, A. Babcock, M. Jensen, T. Owens, and B. Finsen, unpublished observations). Chemokine expression in the denervated hippocampus promotes immune cell infiltration, and peripheral immune cell dysfunction may tap into such innate glial responses. Whether this is one mechanism leading toward CNS autoimmunity, such as in MS, is of interest (Carson and Sutcliffe, 1999; Becher et al., 2000; Owens et al., 2001; Carson, 2002).

Glia produce chemokines in other models of CNS injury. RANTES/CCL5, MCP-1/CCL2, IP-10/CXCL10, MIP-1 $\alpha /$ CCL3, and MIP-1 $\beta /$ CCL 4 were elevated after cuprizone-induced demyelination (McMahon et al., 2001). Aspiration lesions induced MCP-1/CCL2 expression in the visual cortex and in the thalamic nuclei before retrograde degeneration (Muessel et al., 2000). Acute excitotoxic injury elicited by local injection of NMDA or kainic acid induced MCP-1/CCL2 expression by macrophage/ microglia and astrocytes (Calvo et al., 1996; Szaflarski et al., 1998). In our study, MCP-1/CCL2+ cells colocalized with both $\mathrm{iba1}+$ microglia and GFAP + astrocytes. Other studies of CNS inflammation have documented endothelial or neuronal expression of MCP-1/CCL2 (Flugel et al., 2001b; Thibeault et al., 2001). Although we cannot exclude the possibility that these cells contributed to MCP-1/CCL2 expression, our data suggest that most, if not all, MCP-1/CCL2 is produced by astrocytes and microglia. Proportions of microglia versus astrocytes were lower at the site of axonal transection. Similar proportions were seen at $3 \mathrm{hr}$ (data not shown), arguing against this being a consequence of the kinetics of degeneration. There may be microenvironmental differences between the two sites. This could reflect tissue injury/necrosis versus apoptosis, or differences in the neurochemical milieu. The innate capacity for glia to respond to injury with chemokine expression may reflect a role in normal brain function (Mennicken et al., 1999; Bajetto et al., 2002). Our observation, that microglia and astrocytes in the denervated hippocampus express chemokines, speaks for an innate program of glial reactivity that is induced by axonal injury.

The specific stimulus for glial activation has yet to be determined. Components of pathogens may trigger microglial activation via Toll-like receptors (Nguyen et al., 2002). Glial activation might result as a consequence of disrupted neurotransmission after CNS injury. Altered levels of potassium, purines, or pyrimidines may signal neuronal damage and activate glia (Khanna et al., 2001; Chakfe et al., 2002; Inoue, 2002). $\beta$ amyloid and gangliosides have also been shown to stimulate microglial activation (Pyo et al., 1999; Tan et al., 1999). Many proteins not normally found in the CNS may serve as glial activating factors, either by gaining access to sites of injury or local production by resident cells. Thus, thrombin, complement fragments, heat shock proteins, and cytokines have been implicated in glial activation (Klein et al., 1997; Moller et al., 1997; Bhat and Sharma, 1999; Moller et al., 2000; Kalla et al., 2001; Hanisch, 2002; Kakimura et al., 2002). Chemokines themselves may activate glia. Fractalkine/ CX3CL1 has been proposed to mediate microglial activation via $\mathrm{CX}_{3} \mathrm{CR} 1$ after facial motor nerve axotomy or ischemia (Harrison et al., 1998; Tarozzo et al., 2002). MCP-1/CCL2 has been proposed to initiate microglial activation in response to retrograde degeneration after injury to facial nerve (Flugel et al., 2001b) or visual cortex (Muessel et al., 2002). In our study, however, glial reactivity was not noticeably diminished in either CCR2- or CCR5-deficient mice. Although the stimulus that triggers glial reactivity after entorhinodentate axotomy remains undefined, our results show that glia generate a broad-spectrum chemokine response in response to CNS injury that triggers leukocyte infiltration.

There is a growing appreciation that CNS infiltration by both macrophages and T cells may be neuroprotective (Schwartz et al., 1999). Infiltrating macrophages promote regeneration or repair of injured neurons in the CNS by phagocytosing myelin debris (David et al., 1990; Schwartz et al., 1999). Whether macrophages can enter and exert this repair function may depend on MCP-1/ CCL2 (Siebert et al., 2000; Ousman and David, 2001; Ma et al., 2002). After entorhinodentate lesions, regenerative axonal sprouting responses help restore hippocampal function (Fagan and Gage, 1994). Macrophages recruited to the lesion-reactive hippocampus may contribute to the efficacy of this response by phagocytosing myelin debris. T cells not only infiltrate the facial nucleus (Raivich et al., 1998) but also promote facial motorneuron survival (Serpe et al., 1999). Myelin-specific Th2 cells downregulate microglial activation in hippocampal slice cultures, supporting an anti-inflammatory role for these cells in neuroinflammation (Gimsa et al., 2001); however, normal cholinergic sprouting was observed in the denervated hippocampus of T celldeficient nude rats (Fagan and Gage, 1994). Whether T cells that infiltrate the denervated hippocampus are neuroprotective can only be speculated at this point.

Taken together, our observations suggest that early glial production of MCP-1/CCL2 is an innate response to axonal injury that promotes leukocyte infiltration. This role for glial-derived MCP-1/CCL2 complements that for the CCR8 ligand TCA-3/ CCL1 in T cell infiltration in EAE (Murphy et al., 2002), thereby making a case for glial-derived chemokines as critical regulators of immune-CNS interaction. The innate glial responses that direct CNS-leukocyte interactions must also fulfill intrinsic roles within the CNS, and therefore play a dual role in regulation of CNS physiology and homeostasis.

\section{References}

Babcock A, Owens T (2003) Chemokines in experimental autoimmune encephalomyelitis and multiple sclerosis. Adv Exp Med Biol 520:120-132.

Bajetto A, Bonavia R, Barbero S, Schettini G (2002) Characterization of chemokines and their receptors in the central nervous system: physiopathological implications. J Neurochem 82:1311-1329.

Becher B, Prat A, Antel JP (2000) Brain-immune connection: immunoregulatory properties of CNS-resident cells. Glia 29:293-304.

Bechmann I, Peter S, Beyer M, Gimsa U, Nitsch R (2001) Presence of B7-2 (CD86) and lack of B7-1 (CD(80) on myelin phagocytosing MHC-IIpositive rat microglia is associated with nondestructive immunity in vivo. FASEB J 15:1086-1088.

Berman JW, Guida MP, Warren J, Amat J, Brosnan CF (1996) Localization of monocyte chemoattractant peptide-1 expression in the central nervous system in experimental autoimmune encephalomyelitis and trauma in the rat. J Immunol 156:3017-3023. 
Bhat NR, Sharma KK (1999) Microglial activation by the small heat shock protein, alpha-crystallin. NeuroReport 10:2869-2873.

Biernacki K, Prat A, Blain M, Antel JP (2001) Regulation of Th1 and Th2 lymphocyte migration by human adult brain endothelial cells. J Neuropathol Exp Neurol 60:1127-1136.

Calvo CF, Yoshimura T, Gelman M, Mallat M (1996) Production of monocyte chemotactic protein-1 by rat brain macrophages. Eur J Neurosci 8:1725-1734.

Carson MJ (2002) Microglia as liaisons between the immune and central nervous systems: functional implications for multiple sclerosis. Glia 40:218-231.

Carson MJ, Sutcliffe JG (1999) Balancing function vs. self defense: the CNS as an active regulator of immune responses. J Neurosci Res 55:1-8.

Carson MJ, Reilly CR, Sutcliffe JG, Lo D (1998) Mature microglia resemble immature antigen-presenting cells. Glia 22:72-85.

Carson MJ, Sutcliffe JG, Campbell IL (1999) Microglia stimulate naive T-cell differentiation without stimulating T-cell proliferation. J Neurosci Res 55:127-134.

Chakfe Y, Seguin R, Antel JP, Morissette C, Malo D, Henderson D, Seguela P (2002) ADP and AMP induce interleukin-1beta release from microglial cells through activation of ATP-primed P2X7 receptor channels. J Neurosci 22:3061-3069.

David S, Bouchard C, Tsatas O, Giftochristos N (1990) Macrophages can modify the nonpermissive nature of the adult mammalian central nervous system. Neuron 5:463-469.

Fagan AM, Gage FH (1994) Mechanisms of sprouting in the adult central nervous system: cellular responses in areas of terminal degeneration and reinnervation in the rat hippocampus. Neuroscience 58:705-725.

Fife BT, Huffnagle GB, Kuziel WA, Karpus WJ (2000) CC chemokine receptor 2 is critical for induction of experimental autoimmune encephalomyelitis. J Exp Med 192:899-906.

Flugel A, Bradl M, Kreutzberg GW, Graeber MB (2001a) Transformation of donor-derived bone marrow precursors into host microglia during autoimmune CNS inflammation and during the retrograde response to axotomy. J Neurosci Res 66:74-82.

Flugel A, Hager G, Horvat A, Spitzer C, Singer GM, Graeber MB, Kreutzberg GW, Schwaiger FW (2001b) Neuronal MCP-1 expression in response to remote nerve injury. J Cereb Blood Flow Metab 21:69-76.

Fuentes M, Durham S, Swerdel M, Lewin A, Barton D, Megill J, Bravo R, Lira S (1995) Controlled recruitment of monocytes and macrophages to specific organs through transgenic expression of monocyte chemoattractant protein-1. J Immunol 155:5769-5776.

Gimsa U, Wolf SA, Haas D, Bechmann I, Nitsch R (2001) Th2 cells support intrinsic anti-inflammatory properties of the brain. J Neuroimmunol 119:73-80.

Glabinski AR, Tani M, Tuohy VK, Tuthill RJ, Ransohoff RM (1995) Central nervous system chemokine mRNA accumulation follows initial leukocyte entry at the onset of acute murine experimental autoimmune encephalomyelitis. Brain Behav Immun 9:315-330.

Glabinski AR, Tani M, Strieter RM, Tuohy VK, Ransohoff RM (1997) Synchronous synthesis of alpha- and beta-chemokines by cells of diverse lineage in the central nervous system of mice with relapses of chronic experimental autoimmune encephalomyelitis. Am J Pathol 150:617-630.

Godiska R, Chantry D, Dietsch GN, Gray PW (1995) Chemokine expression in murine experimental allergic encephalomyelitis. J Neuroimmunol 58:167-176.

Gu L, Tseng SC, Rollins BJ (1999) Monocyte chemoattractant protein-1. Chem Immunol 72:7-29.

Hanisch UK (2002) Microglia as a source and target of cytokines. Glia 40:140-155.

Harrison JK, Jiang Y, Chen S, Xia Y, Maciejewski D, McNamara RK, Streit WJ, Salafranca MN, Adhikari S, Thompson DA, Botti P, Bacon KB, Feng L (1998) Role for neuronally derived fractalkine in mediating interactions between neurons and CX3CR1-expressing microglia. Proc Natl Acad Sci USA 95:10896-10901.

Huang D, Wang J, Kivisakk P, Rollins BJ, Ransohoff RM (2001) Absence of monocyte chemoattractant protein 1 in mice leads to decreased local macrophage recruitment and antigen-specific $\mathrm{T}$ helper cell type $1 \mathrm{im}$ mune response in experimental autoimmune encephalomyelitis. J Exp Med 193:713-726.

Huang D, Tani M, Wang J, Han Y, He TT, Weaver J, Charo IF, Tuohy VK, Rollins BJ, Ransohoff RM (2002) Pertussis toxin-induced reversible en- cephalopathy dependent on monocyte chemoattractant protein-1 overexpression in mice. J Neurosci 22:10633-10642.

Inoue K (2002) Microglial activation by purines and pyrimidines. Glia 40:156-163.

Ito D, Imai Y, Ohsawa K, Nakajima K, Fukuuchi Y, Kohsaka S (1998) Microglia-specific localisation of a novel calcium binding protein, Iba1. Brain Res Mol Brain Res 57:1-9.

Izikson L, Klein RS, Charo IF, Weiner HL, Luster AD (2000) Resistance to experimental autoimmune encephalomyelitis in mice lacking the CC chemokine receptor (CCR)2. J Exp Med 192:1075-1080.

Jensen MB, Gonzalez B, Castellano B, Zimmer J (1994) Microglial and astroglial reactions to anterograde axonal degeneration: a histochemical and immunocytochemical study of the adult rat fascia dentata after entorhinal perforant path lesions. Exp Brain Res 98:245-260.

Jensen MB, Finsen B, Zimmer J (1997) Morphological and immunophenotypic microglial changes in the denervated fascia dentata of adult rats: correlation with blood-brain barrier damage and astroglial reactions. Exp Neurol 143:103-116.

Jensen MB, Hegelund IV, Lomholt ND, Finsen B, Owens T (2000) IFN $\gamma$ enhances microglial reactions to hippocampal axonal degeneration. J Neurosci 20:3612-3621.

Kakimura J, Kitamura Y, Takata K, Umeki M, Suzuki S, Shibagaki K, Taniguchi T, Nomura Y, Gebicke-Haerter PJ, Smith MA, Perry G, Shimohama S (2002) Microglial activation and amyloid-beta clearance induced by exogenous heat-shock proteins. FASEB J 16:601-603.

Kalla R, Liu Z, Xu S, Koppius A, Imai Y, Kloss CU, Kohsaka S, Gschwendtner A, Moller JC, Werner A, Raivich G (2001) Microglia and the early phase of immune surveillance in the axotomized facial motor nucleus: impaired microglial activation and lymphocyte recruitment but no effect on neuronal survival or axonal regeneration in macrophage-colony stimulating factor-deficient mice. J Comp Neurol 436:182-201.

Kennedy KJ, Strieter RM, Kunkel SL, Lukacs NW, Karpus WJ (1998) Acute and relapsing experimental autoimmune encephalomyelitis are regulated by differential expression of the CC chemokines macrophage inflammatory protein-1alpha and monocyte chemotactic protein-1. J Neuroimmunol 92:98-108.

Khanna R, Roy L, Zhu X, Schlichter LC (2001) K+ channels and the microglial respiratory burst. Am J Physiol Cell Physiol 280:C796-806.

Klein MA, Moller JC, Jones LL, Bluethmann H, Kreutzberg GW, Raivich G (1997) Impaired neuroglial activation in interleukin-6 deficient mice. Glia 19:227-233.

Kuziel WA, Morgan SJ, Dawson TC, Griffin S, Smithies O, Ley K, Maeda N (1997) Severe reduction in leukocyte adhesion and monocyte extravasation in mice deficient in CC chemokine receptor 2. Proc Natl Acad Sci USA 94:12053-12058.

Kuziel WA, Dawson TC, Quinones M, Garavito E, Chenaux G, Ahuja SS, Reddick RL, Maeda N (2003) CCR5 deficiency is not protective in the early stages of atherogenesis in apoE knockout mice. Atherosclerosis 167:25-32.

Ma M, Wei T, Boring L, Charo IF, Ransohoff RM, Jakeman LB (2002) Monocyte recruitment and myelin removal are delayed following spinal cord injury in mice with CCR2 chemokine receptor deletion. J Neurosci Res 68:691-702.

Maatta JA, Sjoholm UR, Nygardas PT, Salmi AA, Hinkkanen AE (1998) Neutrophils secreting tumor necrosis factor alpha infiltrate the central nervous system of BALB/c mice with experimental autoimmune encephalomyelitis. J Neuroimmunol 90:162-175.

Martiney JA, Rajan AJ, Charles PC, Cerami A, Ulrich PC, Macphail S, Tracey KJ, Brosnan CF (1998) Prevention and treatment of experimental autoimmune encephalomyelitis by CNI-1493, a macrophage-deactivating agent. J Immunol 160:5588-5595.

McMahon EJ, Cook DN, Suzuki K, Matsushima GK (2001) Absence of macrophage-inflammatory protein-1alpha delays central nervous system demyelination in the presence of an intact blood-brain barrier. J Immunol 167:2964-2971.

McManus C, Berman JW, Brett FM, Staunton H, Farrell M, Brosnan CF (1998) MCP-1, MCP-2 and MCP-3 expression in multiple sclerosis lesions: an immunohistochemical and in situ hybridization study. J Neuroimmunol 86:20-29.

Meng SZ, Oka A, Takashima S (1999) Developmental expression of monocyte chemoattractant protein-1 in the human cerebellum and brainstem. Brain Dev 21:30-35. 
Mennicken F, Maki R, de Souza EB, Quirion R (1999) Chemokines and chemokine receptors in the CNS: a possible role in neuroinflammation and patterning. Trends Pharmacol Sci 20:73-78.

Moller T, Nolte C, Burger R, Verkhratsky A, Kettenmann H (1997) Mechanisms of $\mathrm{C} 5 \mathrm{a}$ and $\mathrm{C} 3 \mathrm{a}$ complement fragment-induced $\left[\mathrm{Ca}^{2+}\right]$ i signaling in mouse microglia. J Neurosci 17:615-624.

Moller T, Hanisch UK, Ransom BR (2000) Thrombin-induced activation of cultured rodent microglia. J Neurochem 75:1539-1547.

Muessel MJ, Berman NE, Klein RM (2000) Early and specific expression of monocyte chemoattractant protein-1 in the thalamus induced by cortical injury. Brain Res Mol Brain Res 870:211-221.

Muessel MJ, Klein RM, Wilson AM, Berman NE (2002) Ablation of the chemokine monocyte chemoattractant protein-1 delays retrograde neuronal degeneration, attenuates microglial activation, and alters expression of cell death molecules. Brain Res Mol Brain Res 103:12-27.

Murphy CA, Hoek RM, Wiekowski MT, Lira SA, Sedgwick JD (2002) Interactions Between hemopoietically derived TNF and central nervous system-resident glial chemokines underlie initiation of autoimmune inflammation in the brain. J Immunol 169:7054-7062.

Nguyen MD, Julien JP, Rivest S (2002) Innate immunity: the missing link in neuroprotection and neurodegeneration? Nat Rev Neurosci 3:216-227.

Nygardas PT, Maatta JA, Hinkkanen AE (2000) Chemokine expression by central nervous system resident cells and infiltrating neutrophils during experimental autoimmune encephalomyelitis in the BALB/c mouse. Eur J Immunol 30:1911-1918.

Ousman SS, David S (2001) MIP-1 $\alpha$, MCP-1, GM-CSF, and TNF- $\alpha$ control the immune cell response that mediates rapid phagocytosis of myelin from the adult mouse spinal cord. J Neurosci 21:4649-4656.

Owens T, Wekerle H, Antel J (2001) Genetic models for CNS inflammation. Nat Med 7:161-166.

Priller J, Persons DA, Klett FF, Kempermann G, Kreutzberg GW, Dirnagl U (2001) Neogenesis of cerebellar Purkinje neurons from gene-marked bone marrow cells in vivo. J Cell Biol 155:733-738.

Pyo H, Joe E, Jung S, Lee SH, Jou I (1999) Gangliosides activate cultured rat brain microglia. J Biol Chem 274:34584-34589.

Raivich G, Jones LL, Kloss CU, Werner A, Neumann H, Kreutzberg GW (1998) Immune surveillance in the injured nervous system: T-lymphocytes invade the axotomized mouse facial motor nucleus and aggregate around sites of neuronal degeneration. J Neurosci 18:5804-5816.

Rajan AJ, Asensio VC, Campbell IL, Brosnan CF (2000) Experimental autoimmune encephalomyelitis on the SJL mouse: effect of gamma delta T cell depletion on chemokine and chemokine receptor expression in the central nervous system. J Immunol 164:2120-2130.

Renno T, Zeine R, Girard JM, Gillani S, Dodelet V, Owens T (1994) Selective enrichment of Th1 CD45RBlow CD4 + T cells in autoimmune infiltrates in experimental allergic encephalomyelitis. Int Immunol 6:347-354.

Renno T, Krakowski M, Piccirillo C, Lin JY, Owens T (1995) TNF-alpha expression by resident microglia and infiltrating leukocytes in the central nervous system of mice with experimental allergic encephalomyelitis. Regulation by Th1 cytokines. J Immunol 154:944-953.

Renno T, Taupin V, Bourbonniere L, Verge G, Tran E, De Simone R, Krakowski M, Rodriguez M, Peterson A, Owens T (1998) Interferongamma in progression to chronic demyelination and neurological deficit following acute EAE. Mol Cell Neurosci 12:376-389.

Schwartz M, Moalem G, Leibowitz-Amit R, Cohen IR (1999) Innate and adaptive immune responses can be beneficial for CNS repair. Trends Neurosci 22:295-299.

Sedgwick JD, Schwender S, Imrich H, Dorries R, Butcher GW, ter Meulen V
(1991) Isolation and direct characterization of resident microglial cells from the normal and inflamed central nervous system. Proc Natl Acad Sci USA 88:7438-7442.

Sedgwick JD, Ford AL, Foulcher E, Airriess R (1998) Central nervous system microglial cell activation and proliferation follows direct interaction with tissue-infiltrating T cell blasts. J Immunol 160:5320-5330.

Serpe CJ, Kohm AP, Huppenbauer CB, Sanders VM, Jones KJ (1999) Exacerbation of facial motoneuron loss after facial nerve transection in severe combined immunodeficient (scid) mice. J Neurosci 19:RC7(1-5).

Siebert H, Sachse A, Kuziel WA, Maeda N, Bruck W (2000) The chemokine receptor CCR2 is involved in macrophage recruitment to the injured peripheral nervous system. J Neuroimmunol 110:177-185.

Simpson JE, Newcombe J, Cuzner ML, Woodroofe MN (1998) Expression of monocyte chemoattractant protein-1 and other beta-chemokines by resident glia and inflammatory cells in multiple sclerosis lesions. J Neuroimmunol 84:238-249.

Simpson JE, Newcombe J, Cuzner ML, Woodroofe MN (2000) Expression of the interferon-gamma-inducible chemokines IP-10 and Mig and their receptor, CXCR3, in multiple sclerosis lesions. Neuropathol Appl Neurobiol 26:133-142.

Sorensen TL, Tani M, Jensen J, Pierce V, Lucchinetti C, Folcik VA, Qin S, Rottman J, Sellebjerg F, Strieter RM, Frederiksen JL, Ransohoff RM (1999) Expression of specific chemokines and chemokine receptors in the central nervous system of multiple sclerosis patients. J Clin Invest 103:807-815.

Sorensen TL, Trebst C, Kivisakk P, Klaege KL, Majmudar A, Ravid R, Lassmann H, Olsen DB, Strieter RM, Ransohoff RM, Sellebjerg F (2002) Multiple sclerosis: a study of CXCL10 and CXCR3 co-localization in the inflamed central nervous system. J Neuroimmunol 127:59-68.

Szaflarski J, Ivacko J, Liu XH, Warren JS, Silverstein FS (1998) Excitotoxic injury induces monocyte chemoattractant protein-1 expression in neonatal rat brain. Brain Res Mol Brain Res 55:306-314.

Tan J, Town T, Paris D, Mori T, Suo Z, Crawford F, Mattson MP, Flavell RA, Mullan M (1999) Microglial activation resulting from CD40-CD40L interaction after beta-amyloid stimulation. Science 286:2352-2355.

Tarozzo G, Campanella M, Ghiani M, Bulfone A, Beltramo M (2002) Expression of fractalkine and its receptor, CX3CR1, in response to ischaemiareperfusion brain injury in the rat. Eur J Neurosci 15:1663-1668.

Thibeault I, Laflamme N, Rivest S (2001) Regulation of the gene encoding the monocyte chemoattractant protein 1 (MCP-1) in the mouse and rat brain in response to circulating LPS and proinflammatory cytokines. J Comp Neurol 434:461-477.

Tran EH, Hoekstra K, van Rooijen N, Dijkstra CD, Owens T (1998) Immune invasion of the central nervous system parenchyma and experimental allergic encephalomyelitis, but not leukocyte extravasation from blood, are prevented in macrophage-depleted mice. J Immunol 161:3767-3775

Tran EH, Kuziel WA, Owens T (2000) Induction of experimental autoimmune encephalomyelitis in C57BL/6 mice deficient in either the chemokine macrophage inflammatory protein-1alpha or its CCR5 receptor. Eur J Immunol 30:1410-1415.

Vallieres L, Sawchenko PE (2003) Bone marrow-derived cells that populate the adult mouse brain preserve their hematopoietic identity. J Neurosci 23:5197-5207.

Van Der Voorn P, Tekstra J, Beelen RH, Tensen CP, Van Der Valk P, De Groot CJ (1999) Expression of MCP-1 by reactive astrocytes in demyelinating multiple sclerosis lesions. Am J Pathol 154:45-51. 